\title{
Population structure and genetic variability of mainland and insular populations of the Neotropical water rat, Nectomys squamipes (Rodentia, Sigmodontinae)
}

\author{
Francisca C. Almeida ${ }^{1,2}$, Luana S. Maroja ${ }^{1}$, Miguel A.M. Moreira ${ }^{2}$, Héctor N. Seuánez ${ }^{1,2}$ and Rui Cerqueira ${ }^{3}$ \\ ${ }^{1}$ Universidade Federal do Rio de Janeiro, Departamento de Genética, Rio de Janeiro, RJ, Brazil. \\ ${ }^{2}$ Instituto Nacional de Câncer, Divisáo de Genética, Rio de Janeiro, RJ, Brazil. \\ ${ }^{3}$ Universidade Federal do Rio de Janeiro, Departamento de Ecologia, Rio de Janeiro, RJ, Brazil.
}

\begin{abstract}
Seven microsatellite loci were used to investigate the genetic variability and structure of six mainland and two island populations of the Neotropical water rat Nectomys squamipes, a South American semi-aquatic rodent species with a wide distribution. High levels of variability were found within mainland populations while island populations were less variable but the more differentiated in respect to allele number and frequency. The time of biological divergence between mainland and island populations coincided with geological data. A significant geographic structure was found in mainland populations $(\theta=0.099 ; \rho=0.086)$ although the degree of differentiation was relatively low in respect to the distance between surveyed localities (24 to $740 \mathrm{~km}$ ). Genetic and geographic distances were not positively correlated as previously found with random amplified polymorphic DNA (RAPD) markers. Significant but low genetic differentiation in the mainland and lack of isolation by distance can be explained by large population size and/or recent population expansion. Additionally, the agreement between the age of geologic events (sea level fluctuations) and divergence times for insular populations points to a good reference for molecular clock calibration to associate recent environmental changes and the distribution pattern of small mammals in the Brazilian Atlantic Forest.
\end{abstract}

Key words: microsatellites, population genetics, islands, population expansion, population size, divergence time.

Received: September 27, 2004; Accepted: March 22, 2005.

Introduction

The Neotropical water rat, Nectomys squamipes (Brants, 1827), is a semi-aquatic rodent species widely distributed along rivers and streams of the Atlantic Forest and Cerrado biomes in Eastern Brazil. Ecological studies showed that these rodents rarely move farther than $20 \mathrm{~m}$ from streams, their home range being restricted to a range of from 200 to $14,808 \mathrm{~m}^{2}$ and $90 \%$ of displacements occurring only in the water or along riverbanks (Bergallo, 1995, MV Vieira, personal communication). These rodents rely on a generalist diet and the availability of riverbank habitats seems to be the only factor affecting their distribution that might also occur in the proximity of urban areas (Gentile, et al., 2000), although their semi-aquatic habits may hinder migration between river basins and across mountain ranges.

Send correspondence to Héctor N. Seuánez. Instituto Nacional de Câncer, Seção de Genética, Rua André Cavalcante 37, $4^{\circ}$ andar 20231-050 Rio de Janeiro, RJ, Brazil. E-mail: genetics@inca. gov.br.
Small non-flying mammals have been generally thought to show limited dispersal ability resulting in a pattern of structured genetic variability (Koenig et al., 1996; Patton et al., 1996). A six-year capture-recapture study of $N$. squamipes in a small area $\left(3 \mathrm{~km}^{2}\right)$ detected only $10 \mathrm{mi}-$ grants (mostly males) out of 162 recaptured individuals with all the displacements occurring between adjacent sites (LS Maroja, personal observation). Microsatellite data, when analyzed in this population, showed significant, although minor, differentiation between collection sites (Maroja et al., 2003a). Based on these results and theoretical models, wider areas would be expected to exhibit a higher degree of differentiation among sites. Contrary to these expectations, however, the morphology of $N$. squamipes was found to be fairly homogeneous across its wide geographic range (Bonvicino, 1994) and this low degree of differentiation between populations was confirmed by random amplified polymorphic DNA (RAPD) studies (Almeida et al., 2000a). Since morphology may be subject to balancing selection and RAPD markers have well known 
limitations and are less efficient in detecting differentiation than microsatellite markers (Lynch and Milligan, 1994; Ross et al., 1999; Lougheed et al., 2000), we decided to use microsatellite markers to re-analyze the population samples previously studied using RAPD.

Although sigmodontine rodents are ecologically important and represent a significant portion of all South American mammalian species, only a few molecular studies have been conducted on the geographic variation of these rodents (e.g. Patton et al., 1996; Loxterman et al., 1998). To date, the only published report of a population study using microsatellites is that of Maroja et al. (2003a) who studied N. squamipes in a restricted area. The lack of taxonomic problems with this rodent along with its well-researched ecology and wide and welldefined geographic range make $N$. squamipes a good candidate for studies of population dynamics. Another important reason for studying the population genetics of $N$. squamipes is that it is a natural primary host for Schistosoma mansoni. Although it is apparently unaffected by this parasite, infected $N$. squamipes can potentially spread $S$. mansoni to uninfected areas (D'Andrea et al., 2000; Maroja et al. 2003a).

In this paper we report an analysis of microsatellite data from five $N$. squamipes populations previously studied with RAPD along with data for one additional mainland and two insular N. squamipes populations. These islands were expected to have isolated populations which might be useful as comparisons for evaluating the role of dispersal in determining the genetic structure of mainland populations. To check whether the island populations were true isolates we calculated genetic distances and compared them with geological data on Holocene sea level fluctuations.

\section{Materials and Methods}

\section{Population samples}

One hundred and ten Nectomys squamipes were captured with Sherman or Tomahawk live traps in eight Brazilian localities (Figure 1), six mainland sites at Glicério (GL; $\mathrm{n}=26$ ); Fazenda União ( $\mathrm{FU} ; \mathrm{n}=8)$; Sumidouro (SU; $\mathrm{n}=18$ ), Tarituba (TA; $\mathrm{n}=21$ ) in Rio de Janeiro State; Pedreiras $(\mathrm{PD} ; \mathrm{n}=10)$ in São Paulo State and Fazenda Canoas $(\mathrm{FC} ; \mathrm{n}=6)$ in Minas Gerais State and two insular sites Ilha da Marambaia (IM; $\mathrm{n}=8$ ) and Ilha Grande (IG; $\mathrm{n}=13$ ) in Rio de Janeiro State. The number of specimens is shown in the parentheses. Voucher specimens were deposited in the Museu Nacional, Rio de Janeiro, Brazil. Samples from GL, FU, SU, PD and FC had previously been analysed using RAPD (Almeida et al., 2000a). Geographic distances between mainland localities ranged from 23.7 to $741.5 \mathrm{~km}$. Ilha Grande (IG) is $3.3 \mathrm{~km}$ from the mainland and has an area of $193 \mathrm{~km}^{2}$ while Ilha de Marambaia (IM) is about four times smaller but is presently connected to the mainland by a small sand strip that probably appeared after the separa-

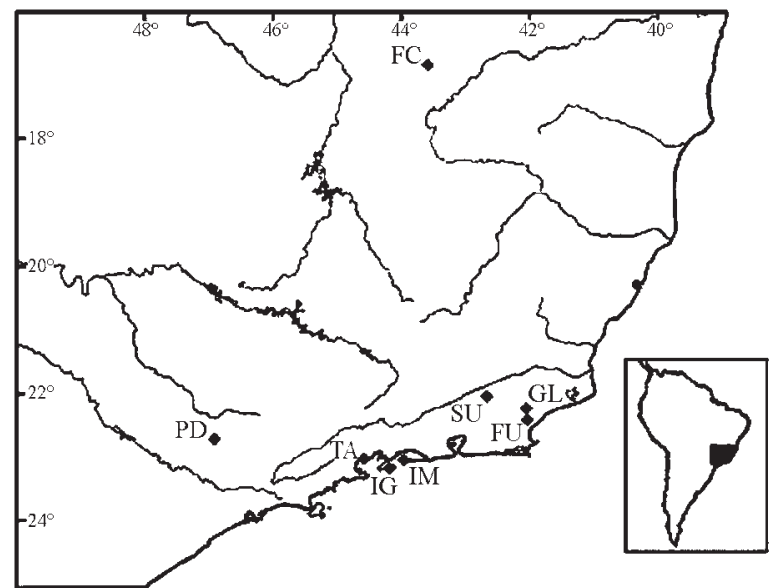

Figure 1 - Collection sites of N. squamipes in eastern Brazil.

tion of the island from the mainland some 7,000 years ago (Martins and Villwock, 1987; Cerqueira, 2000).

Most animals were sacrificed and their liver tissue aliquots were preserved in absolute ethanol. Blood was collected from the hind foot of several live Ilha Grande animals and kept frozen with EDTA until extraction. Total DNA was extracted from the liver samples following Smith et al. (1987) and from blood samples following Sambrook et al. (1989).

\section{Microsatellite polymorphism analysis}

Seven microsatellite markers (Nec08, Nec12, Nec14, Nec15, Nec18, Nec23 and Nec28) were PCR amplified as previously described (Almeida et al., 2000b; Maroja et al., 2003b). The forward primer of each locus was labeled with a fluorescent dye (NED, HEX or 6-FAM) and the PCR products run in an automated ABI 377 sequencer with GeneScan 500-ROX (Applied Biosystems) as internal size standard and analyzed with the GeneScan program version 1.2.2 (Applied Biosystems).

Linkage disequilibrium between loci was tested with Fisher's exact test and the Markov chain procedure with 500,000 iterations and 1,000 de-memorization steps using the Genepop program version 3.4 (Raymond and Rousset, 1995a).

\section{Microsatellite variation}

For each population, the number of alleles $(A)$, allelic richness $\left(\mathrm{A}_{\mathrm{R}}\right.$; El Mousadik and Petit, 1996), observed direct-count heterozygosity $\left(H_{D C}\right)$ and unbiased expected heterozygosity $\left(H_{E}\right.$; Nei, 1978) were computed for each locus using the Fstat program version 2.9.3 (Goudet, 2001). Hardy-Weinberg equilibrium (HWE) was tested with Fisher's exact test and the Markov chain procedure (Guo and Thompson, 1992) with 1,000 de-memorization steps and 100,000 iterations using the Arlequin program version 
2.0 (Scheneider et al., 2000). This test was performed separately for each population and each locus.

\section{Population differentiation and isolation by distance}

Genic (allelic frequency) differentiation between mainland populations was assessed with Fisher's exact test (Raymond and Rousset, 1995b) and genotypic differentiation between these populations using the log-likelihood $\mathrm{G}$ test (Goudet et al., 1996), both statistics being calculated using the Genepop program version 3.4 (Raymond and Rousset, 1995a) and 1,000 iterations. Quantitative assessments of differentiation between the same populations were calculated with the $\mathrm{F}_{\mathrm{ST}}$ and $\mathrm{R}_{\mathrm{ST}}$ estimators. The $\mathrm{R}_{\mathrm{ST}}$ statistic takes into account the stepwise mutation model (SMM) and for this reason should be more sensitive in detecting differentiation with microsatellite data (Slatkin, 1995). The $F_{\text {ST }}$ estimator $(\theta)$ was obtained following Weir and Cockerham (1984) using Fstat 2.9.3, with mean, standard error and 95\% confidence intervals (CI) calculated with permutations over loci. The $\mathrm{R}_{\mathrm{ST}}$ (Slatkin, 1995) estimator $(\rho)$ was calculated using significance values established with the RstCalc program version 2.2 (Goodman, 1997) using 1,000 permutations. Pairwise population estimates were calculated for both $\theta$ and $\rho$.

To estimate the contribution of the island populations to the global diversity of $N$. squamipes we carried out a three-level AMOVA (Analysis of Molecular Variance) using the Arlequin program version 2.0. Partitions of microsatellite data variance within populations, between populations and between the mainland group and the island group were calculated according to Excoffier et al. (1992). Differences in genetic diversity between mainland populations on one side, and insular populations on the other were verified by comparing allelic richness and observed heterozygosity with a permutation test using Fstat 2.9.3.

Following Rousset (1997), isolation by distance (IBD) between mainland populations was tested by comparing $\theta / 1-\theta$ with linear geographic distances between populations with the Mantel test using Genepop 3.4 (2,000 permutations).

\section{Divergence time of insular populations}

The divergence time of the IG and IM populations was estimated as $\mathrm{T}=(\delta \mu)^{2} / 2 v$ (Goldstein et al., 1995) where $\mathrm{T}$ is the divergence time in number of generations, $v$ is the mutation rate and $(\delta \mu)^{2}$ is the a genetic distance estimate for microsatellite data that takes into account the SMM (calculated with RstCalc 2.2). We calculated $(\delta \mu)^{2}$ as the average of pairwise estimates between mainland and island populations and considered the mutation rate to be the same as for the Mus musculus microsatellite loci, i.e. $4.5 \times 10^{-5}$ per generation (Dietrich et al., 1992). A generation time of 110 days was assumed based on data from captive populations (D’Andrea et al., 1996).
Sequential Bonferroni correction (Rice, 1989) was used for assessing statistical significance in all multiple tests.

\section{Results}

All loci analyzed in this study were highly polymorphic, with the total allele number ranging from 12 to 32 (Table1). The Nec23 locus had the largest number of alleles in the total count and within every population except one (TA). No significant linkage disequilibrium was found between any pair of loci either when pooling all populations or when considering each population separately. Genetic diversity within each population was found to be high, with allele number per locus varying from 1 to 17, and roughly related to sample size (Table 1). Private alleles were observed in all populations: seven in GL (in Nec12, Nec14, Nec15, Nec18, Nec23), five in PD (in Nec12, Nec15, $\mathrm{Nec18}$ ), four in FU (in $\mathrm{Nec14}, \mathrm{Nec15}, \mathrm{Nec} 23$ ), six in FC (in $\mathrm{Nec08,} \mathrm{Nec14,} \mathrm{Nec15,} \mathrm{Nec23),} \mathrm{six} \mathrm{in} \mathrm{SU} \mathrm{(in} \mathrm{Nec08,} \mathrm{Nec15,}$ $\mathrm{Nec18}, \mathrm{Nec} 23$ ), four in TA (in Nec12, Nec14, Nec15), two in IM (in Nec23), and two in IG (in Nec08). The highest number of private alleles (10) was found at Nec23 while Nec 28 did not show any private allele.

Mean $H_{E}$ was very high in all mainland populations, averaging 0.82 with a range of 0.625 to 0.970 (Table 1). The highest $H_{E}$ value was found in the FC population despite it having the smallest sample size. The FC population was excluded from estimates of allelic richness so that this parameter could be calculated using a minimum of eight individuals instead of six, increasing its confidence (Table 1).

Departures from HWE were detected in three cases (GL, Nec14; FC, Nec08; IG, Nec15) but these results were not statistically significant following the Bonferroni correction; for the remaining analyses we assumed HWE within populations. These slight departures in specific loci can be accounted for by the presence of population specific null alleles. Since PCR amplifications were generally successful, null alleles were probably rare. An exception to this occurred in the Nec15 locus in the IG population for which three individual DNA samples could not be amplified and two different homozygous genotypes were found but heterozygotes were completely absent.

Both genic and genotypic differentiation between mainland populations were highly significant in each locus and across loci $(\mathrm{p}<0.0005)$. The Nec23 locus has a gap of approximately $40 \mathrm{bp}$ between two consecutive alleles and therefore is not suitable for analysis assuming SMM so we excluded this locus from the $\mathrm{R}_{\mathrm{ST}}$ and $\mathrm{F}_{\mathrm{ST}}$ estimates in order to make them comparable. The $\theta$ estimator of $\mathrm{F}_{\mathrm{ST}}$ was $0.100 \pm 0.012(\mathrm{SE})$ with a $95 \% \mathrm{CI}=0.082$ 0.123 , while the $\rho$ estimator of $\mathrm{R}_{\mathrm{ST}}$ was $0.086 \pm 0.003$ (SE) with a $95 \%$ CI of $0.074-0.172$ (both at $p<0.0005$ ). No 
Table 1 - Genetic diversity of Nectomys squamipes populations.

\begin{tabular}{|c|c|c|c|c|c|c|c|c|c|c|}
\hline \multirow{2}{*}{$\begin{array}{l}\text { Population (number } \\
\text { of specimens) }\end{array}$} & & \multicolumn{9}{|c|}{ Microsatellite locus } \\
\hline & & $\mathrm{Nec08}$ & $\mathrm{Necl} 2$ & $\mathrm{Nec} 14$ & Nec15 & Nec18 & Nec 28 & $\mathrm{Nec} 23$ & Mean & SD \\
\hline \multirow[t]{3}{*}{ Glicério (26) } & $\mathrm{A}\left(\mathrm{A}_{\mathrm{R}}\right)$ & $8(6.20)$ & $14(8.61)$ & $10(6.89)$ & $10(7.23)$ & $14(8.97)$ & $9(6.87)$ & 17 (8.99) & $11.7(7.68)$ & 0.5 \\
\hline & $\mathrm{H}_{\mathrm{DC}}$ & 0.769 & 0.923 & 0.654 & 0.846 & 0.846 & 0.885 & 0.846 & 0.824 & 0.013 \\
\hline & $\mathrm{H}_{\mathrm{E}}$ & 0.814 & 0.883 & 0.811 & 0.827 & 0.911 & 0.848 & 0.903 & 0.857 & 0.006 \\
\hline \multirow[t]{3}{*}{ Fazenda União (8) } & $\mathrm{A}\left(\mathrm{A}_{\mathrm{R}}\right)$ & $3(2.80)$ & $5(4.94)$ & $8(7.53)$ & $6(5.73)$ & $10(8.56)$ & $7(6.00)$ & $11(10.21)$ & $7.1(6.54)$ & 0.4 \\
\hline & $\mathrm{H}_{\mathrm{DC}}$ & 0.40 & 0.800 & 0.900 & 0.600 & 0.900 & 0.700 & 0.778 & 0.725 & 0.026 \\
\hline & $\mathrm{H}_{\mathrm{E}}$ & 0.574 & 0.794 & 0.889 & 0.778 & 0.828 & 0.633 & 0.928 & 0.775 & 0.018 \\
\hline \multirow[t]{3}{*}{ Pedreiras (10) } & $\mathrm{A}\left(\mathrm{A}_{\mathrm{R}}\right)$ & $5(5.00)$ & $8(8.00)$ & $3(3.00)$ & $7(7.00)$ & $5(5.00)$ & $6(6.00)$ & $9(9.00)$ & $6.1(6.1)$ & 0.3 \\
\hline & $\mathrm{H}_{\mathrm{DC}}$ & 0.625 & 0.750 & 0.625 & 1.000 & 0.500 & 0.750 & 1.000 & 0.750 & 0.107 \\
\hline & $\mathrm{H}_{\mathrm{E}}$ & 0.808 & 0.813 & 0.625 & 0.848 & 0.679 & 0.821 & 0.917 & 0.787 & 0.014 \\
\hline \multirow[t]{3}{*}{ Fazenda Canoas (6) } & A & 4 & 7 & 6 & 8 & 7 & 7 & 10 & 7 & 0.2 \\
\hline & $\mathrm{H}_{\mathrm{DC}}$ & 0.167 & 1.000 & 1.000 & 0.833 & 0.833 & 0.833 & 1.000 & 0.809 & 0.042 \\
\hline & $\mathrm{H}_{\mathrm{E}}$ & 0.682 & 0.917 & 0.800 & 0.933 & 0.900 & 0.833 & 0.970 & 0.862 & 0.014 \\
\hline \multirow[t]{3}{*}{ Sumidouro (18) } & $\mathrm{A}\left(\mathrm{A}_{\mathrm{R}}\right)$ & $6(4.72)$ & $10(7.76)$ & $9(7.02)$ & $7(5.99)$ & $11(8.05)$ & $6(4.65)$ & $13(8.45)$ & $8.9(6.66)$ & 0.4 \\
\hline & $\mathrm{H}_{\mathrm{DC}}$ & 0.778 & 0.889 & 0.833 & 0.722 & 0.889 & 0.778 & 0.722 & 0.802 & 0.010 \\
\hline & $\mathrm{H}_{\mathrm{E}}$ & 0.732 & 0.882 & 0.837 & 0.832 & 0.874 & 0.706 & 0.870 & 0.819 & 0.010 \\
\hline \multirow[t]{3}{*}{ Tarituba (21) } & $\mathrm{A}\left(\mathrm{A}_{\mathrm{R}}\right)$ & $5(4.46)$ & $8(6.30)$ & $8(7.11)$ & $9(6.91)$ & $12(8.78)$ & $6(5.44)$ & $8(5.59)$ & $8.0(6.37)$ & 0.3 \\
\hline & $\mathrm{H}_{\mathrm{DC}}$ & 0.571 & 0.809 & 0.952 & 0.857 & 0.857 & 0.905 & 0.762 & 0.816 & 0.018 \\
\hline & $\mathrm{H}_{\mathrm{E}}$ & 0.726 & 0.837 & 0.870 & 0.858 & 0.911 & 0.812 & 0.757 & 0.824 & 0.009 \\
\hline \multirow[t]{3}{*}{ Ilha da Marambaia (8) } & $\mathrm{A}\left(\mathrm{A}_{\mathrm{R}}\right)$ & $3(3.00)$ & $1(1.00)$ & $1(1.00)$ & $5(5.00)$ & $2(2.00)$ & $5(5.00)$ & $10(10.00)$ & $3.9(3.9)$ & 0.5 \\
\hline & $\mathrm{H}_{\mathrm{DC}}$ & 0.750 & 0.000 & 0.000 & 0.625 & 0.125 & 0.875 & 1.000 & 0.482 & 0.061 \\
\hline & $\mathrm{H}_{\mathrm{E}}$ & 0.625 & 0.000 & 0.000 & 0.777 & 0.125 & 0.759 & 0.942 & 0.461 & 0.058 \\
\hline \multirow[t]{3}{*}{ Ilha Grande (13) } & $A\left(A_{R}\right)$ & $2(1.86)$ & $3(2.72)$ & $5(4.56)$ & $2(2.00)$ & $4(3.95)$ & $5(4.52)$ & $7(6.03)$ & $4.0(3.66)$ & 0.3 \\
\hline & $\mathrm{H}_{\mathrm{DC}}$ & 0.154 & 0.308 & 0.615 & 0.000 & 0.923 & 0.692 & 0.692 & 0.483 & 0.048 \\
\hline & $\mathrm{H}_{\mathrm{E}}$ & 0.148 & 0.282 & 0.763 & 0.356 & 0.728 & 0.734 & 0.800 & 0.544 & 0.039 \\
\hline All & $\mathrm{A}$ & 13 & 25 & 16 & 18 & 21 & 12 & 32 & 19.4 & 7.3 \\
\hline
\end{tabular}

$\mathrm{A}=$ number of alleles; $\mathrm{A}_{\mathrm{R}}=$ allelic richness; $H_{D C}=$ direct-count heterozygosity; $H_{E}=$ expected heterozygosity; $\mathrm{SD}=$ standard deviation.

correlation between genetic and geographic distance was apparent $(\mathrm{p}=0.54)$.

The island populations showed significantly lower genetic diversity when compared to the mainland populations, both in terms of $A_{R}$ and $H_{D C}(\mathrm{p}=0.032$ and $\mathrm{p}=0.027$, one-sided probability). Although we grouped both islands when comparing them with the mainland group, these results are valid for both insular populations because they showed very similar estimates of allelic richness and proportion of heterozygotes. The lower variability of island populations reached an extreme value in the IM population, which was monomorphic at two loci ( Necl2 and Nec14) and was the only case of monomorphism. Nevertheless, the genetic diversity found in the two island populations accounted for $6.4 \%$ of the total diversity. Variation between populations within each group, mainland and islands, accounted for $14.03 \%$ of the total variation. Pairwise estimates of $\mathrm{F}_{\mathrm{ST}}$ also confirmed the high degree of differentia- tion of the island populations (Table 2). While pairwise $\theta$ values between mainland populations ranged from 0.045 to 0.145 , pairwise values involving the island populations ranged from 0.224 to 0.469 . The $\rho$ estimator, although lower than $\theta$ in mainland comparisons, indicated even higher differentiation in the islands, with values ranging from 0.340 to 0.623 in pairwise comparisons including insular populations. This result is in accordance with the proposition that $\mathrm{R}_{\mathrm{ST}}$ indexes are more sensitive in comparisons between populations that have been isolated from each other for a longer time (Slatkin, 1995).

Mean genetic distance $(\delta \mu)^{2}$ between IG and the mainland populations was $1.907 \pm 0.175$ ( \pm standard deviation) corresponding to $21,196 \pm 1,941$ generations and to a divergence time of 7,065 \pm 647 years. Similar estimates between IM and mainland populations showed a mean $(\delta \mu)^{2}=0.896 \pm 0.192$ corresponding to $9,955 \pm 2,134$ generations and to $3,319 \pm 711$ years. 
Table 2 - Pairwise estimates of $\theta$ (above diagonal) and $\rho$ (below diagonal) between $N$. squamipes populations. Values in bold are not significant (Bonferroni correction).

\begin{tabular}{lcccccccc}
\hline $\begin{array}{l}\text { Popu- } \\
\text { lation }\end{array}$ & GL & FU & SU & TA & PD & FC & IM & IG \\
\hline GL & & 0.086 & 0.090 & 0.098 & 0.089 & 0.046 & 0.277 & 0.237 \\
FU & 0.169 & & 0.095 & 0.142 & 0.141 & 0.089 & 0.333 & 0.278 \\
SU & 0.079 & $\mathbf{0 . 0 7 7}$ & & 0.099 & 0.119 & 0.071 & 0.282 & 0.266 \\
TA & 0.108 & 0.208 & $\mathbf{0 . 0 6 2}$ & & 0.127 & 0.106 & 0.254 & 0.260 \\
PD & $\mathbf{- 0 . 0 1 1}$ & 0.238 & $\mathbf{0 . 1 2 4}$ & $\mathbf{0 . 1 0 4}$ & & 0.109 & 0.333 & 0.306 \\
FC & $\mathbf{0 . 0 4 6}$ & $\mathbf{0 . 0 2 7}$ & $\mathbf{0 . 0 2 7}$ & $\mathbf{0 . 0 2 1}$ & $\mathbf{0 . 0 3 8}$ & & 0.304 & 0.287 \\
IM & 0.340 & 0.340 & 0.435 & 0.511 & 0.425 & 0.406 & & 0.472 \\
IG & 0.560 & 0.536 & 0.583 & 0.534 & 0.606 & 0.520 & 0.623 & \\
\hline
\end{tabular}

Population key: GL= Glicério; FU = Fazenda União; $\mathrm{SU}=$ Sumidouro $\mathrm{TA}=$ Tarituba; $\mathrm{PD}=$ Pedreiras; $\mathrm{FC}=$ Fazenda Canoas $\mathrm{IM}=$ Ilha da Marambaia; IG = Ilha Grande.

\section{Discussion}

Microsatellite data indicate little differentiation between mainland populations of Nectomys squamipes located between 23 to $740 \mathrm{~km}$ apart. Differentiation estimates were very low even when compared to data of other rodent species (Stewart et al., 1999; Loxterman et al., 1998; Wlasiuk et al., 2003). A likely explanation for our results is that gene flow might be higher than suggested by field studies. The greater differentiation of island populations, in view that they are isolated from any other, may support this hypothesis. However, an alternative explanation that does not conflict with predictions and field estimates of $N$. squamipes dispersal ability is also possible, and low estimates of differentiation might be a consequence of a recent rapid range expansion and/or very large local populations resulting in the absence of migration-drift equilibrium (Kimura and Weiss, 1964; Slatkin, 1989; Slatkin, 1993; Neigel, 1997; Whilock and McCauley, 1999). Lack of isolation by distance, as found in our data, is typical of populations that have not yet attained equilibrium (Hutchinson and Templeton, 1999).

It has been theoretically demonstrated that populations with a large size will attain equilibrium (basically determined by drift) in a very long time, proportional to the size of the population (Slatkin, 1993; Neigel, 1997; Whilock and McCauley, 1999). The high degree of variability observed by us indicates fairly large population sizes on the mainland (Estoup et al., 1995). Another reason for populations not being in equilibrium could be a recent population expansion. The isolation by distance trend (although not significant) found in a considerably smaller area (Maroja et al., 2003a) is in accordance with this hypothesis because equilibrium is first reached between nearby populations (Crow and Aoki, 1984). Although it has been suggested that population expansions result in low genetic variability (Slatkin, 1993), there is empirical evidence that fast expansions may occur without significant loss of variability (Zenger et al., 2003). Tests for population expansion are available for analyzing microsatellite data, but due to the limitations that will be discussed in the next paragraphs, we chose to not use them in the present study. The results presented here, however, provide a preliminary indication of population expansion of a widespread rodent species in eastern South America and should encourage further investigations on the subject.

The microsatellite loci used in this study showed differentiation indexes $(\theta=0.100$ and $\rho=0.086)$ smaller than the index $\left(\mathrm{F}_{\mathrm{ST}}=0.17\right)$ obtained in the previous RAPD analysis that included most of the mainland populations studied here (Almeida et al., 2000a). Differentiation estimates related to the $F$-statistics are negatively correlated with the product of the effective population size $(\mathrm{Ne})$, and the mutation rate $(\mu)$ plus the migration rate $(\mathrm{m})$ (Wright, 1943). This implies that, if $\mu$ is low and $\mathrm{Ne}$ and $\mathrm{m}$ are high, differentiation will be underestimated even in the extreme case of complete isolation (Jin and Chakraborty, 1995; Hedrick, 1999; Balloux et al., 2000). This is especially critical in the case of microsatellites that are susceptible to a high degree of homoplasy due to constraints in allele size (Slatkin, 1995). Microsatellite markers can also be problematic when the number of alleles per locus is relatively high as is the case for some of the loci with more than 20 alleles which were used in this study (Table 1). When a loci has a large number of alleles, very large samples are required for accurately estimating allelic frequency within populations (Leberg, 2002). Simulations by Leberg (2002), suggest that our samples may not be large enough to provide reliable estimates of population differentiation in view of the large number of alleles in most loci. The high variability of each mainland population is, however, a valid finding, indicating large population sizes and relative stability on a recent time scale.

This is the first report of higher differentiation detected with RAPD markers as opposed to microsatellites. Although the $\mathrm{F}_{\mathrm{ST}}$ estimate based on RAPD markers is only slightly higher, it is probably more reliable in view of the limitations of some microsatellite loci as discussed above. Nevertheless, we can reasonably propose that the degree of differentiation between mainland populations is low despite predictions based on the ecology of $N$. squamipes. Sampling a larger number of individuals per population can make differentiation estimates more accurate, although other less variable molecular markers like mtDNA might be more suitable for the study of rodent populations (Matocq et al., 2000).

Despite the small sample sizes we were able to detect a higher differentiation in insular than mainland populations, agreeing with the geographic isolation of the island populations. The divergence time of the IG population estimated from genetic distance $(7,065 \pm 647$ years $)$ was coin- 
cident with the minimum time of geographic separation predicted by geological data (7,000 years before the present (YBP); Martins and Villwock, 1987), while estimates of divergence time of the IM population were considerably lower (3,319 \pm 711 years). One explanation for this discrepancy is a greater migration rate of the IM population because the Ilha da Marambaia is presently connected and closer to the mainland. This connection, however, consists of a very narrow sand-bridge (at some points only 2-meters wide) making water-rat migration rather unlikely. Dispersion by rafting (Loxterman et al., 1998; Patton et al., 1996) and sea level fluctuations might provide a better explanation because two low-sea-level events at ca. 3,900 and 2,700 YBP coincide temporally with the above cited divergence time for the IM population and would have reduced the distance between Marambaia Island and the mainland (Martins and Villwock, 1986).

It is important to remember that most of the divergence of the insular populations is due to their low genetic variability. The existence of fewer alleles than in the mainland populations leads to differences in allelic frequency, which greatly affects differentiation estimates. Reduced diversity is expected to be found in island populations because these populations are more subject to the effects of geographic isolation, smaller population size and founder effect (Grant, 1998). Even in the case of an extreme founder effect, however, the high mutation rates of microsatellites should be enough to restore the genetic variability in these islands given the large number of generations after isolation. Nevertheless, this would not be true if the islands had very small populations and/or went through a recent population bottleneck. At least Ilha Grande seems to be large enough to support a large population. Currently, both islands are relatively well preserved. Ilha Grande has most of its inland area protected and the occupation of the remaining areas is under government control. Ilha da Marambaia is a military area of restricted access and is also largely forested. Both islands, however, were subjected to sugar cane and coffee monoculture from the middle of the XVIII century to the end of the XIX century. Although the human population of these islands has never been large, and $N$. squamipes is capable of living in populated areas, it is difficult to assess whether past activities in these two islands have affected the population of this rodent on these islands. A larger survey of these islands, sampling more sites and using different markers, would be necessary to test for population bottlenecks in the recent history of these populations.

\section{Acknowledgments}

This project was supported by PROBIO/MMA, PRONEX, INCa/FAF and FUJB (Brazil). We are also grateful to Drs. PS D'Andrea, L Geise and CR Bonvicino for providing some of the animals herein analyzed and to our colleagues from the Laboratório de Vertebrados
(UFRJ) and from the team of mammalogists of the Laboratório de Zoologia de Vertebrados (UERJ) for helping us in field work. FC Almeida and LS Maroja were recipients of CAPES graduate grants (Brazil).

\section{References}

Almeida FC, Moreira MAM, Bonvicino CR and Cerqueira R (2000a) RAPD analysis of Nectomys squamipes (Rodentia, Sigmodontinae) populations. Genet Mol Biol 23:793-797.

Almeida FC, Maroja LS, Seuánez HN, Cerqueira R and Moreira MAM (2000b) Identification of five microsatellites in the water rat Nectomys squamipes (Rodentia, Sigmodontinae). Mol Ecol 9:2172-2173.

Balloux F, Brünner H, Lugon-Moulin N, Hausser J and Goudet J (2000) Microsatellites can be misleading: An empirical and simulation study. Evolution 54:1414-1422.

Bergallo HG (1995) Os efeitos da disponibilidade de alimentos e dos fatores climáticos na reprodução, condição, crescimento e uso do espaço por quatro espécies de roedores no sudeste do Brasil. PhD Thesis, Universidade Estadual de Campinas, Campinas.

Bonvicino CR (1994) Especiação do rato d'água Nectomys (Rodentia, Cricetidae). Abordagem cariológica, morfológica e geográfica. PhD Thesis, Universidade Federal do Rio de Janeiro, Rio de Janeiro.

Cerqueira R (2000) Biogeografia das restingas. In: Lacerda LD and Esteves FA (eds), A Ecologia das Restingas e Lagoas. NUPEM/UFRJ, Macaé, pp 65-75.

Crow JF and Aoki K (1984) Group selection for a polygenic behavioral trait: Estimating the degree of population subdivision. Proc Natl Acad Sci USA 81:6073-6077.

D'Andrea PS, Horta C, Cerqueira R and Rey L (1996) Breeding of the water rat (Nectomys squamipes) in the laboratory. Lab Anim 30:369-376.

D'Andrea PS, Maroja LS, Gentile R, Cerqueira R and Rey L (2000) The parasitism of Schistosoma mansoni (DigeniaTrematoda) in a naturally infected water rates, Nectomys squamipes (Rodentia-Sigmondontinae). Parasitology 120:573-582.

Dietrich W, Katz H, Lincoln SE, Shin H, Friedman J, Dracopoli NC and Lander ES (1992) A genetic map of the mouse suitable for typing intraspecific crosses. Genetics 131:423-447.

El Mousadik A and Petit RJ (1996) High level of genetic differentiation for allelic richness among populations of the argan tree [Argania spinosa (L.) Skeels] endemic of Morocco. Theor Appl Genet 92:832-839.

Estoup A, Tailliez C, Cornuet J-M and Solignac M (1995) Size homoplasy and mutational processes of interrupted microsatellite in two bee species, Apis mellifera and Bombus terrestris (Apidae). Mol Biol Evol 12:1074-1084.

Excoffier L, Smouse P and Quattro J (1992) Analysis of molecular variance inferred from metric distances among DNA haplotypes: Application to human mitochondrial DNA restriction data. Genetics 131:479-491.

Gentile R, D'Andrea PS, Cerqueira R and Maroja LS (2000) Population dynamics and reproduction of marsupials in a Brazilian rural area: A five-years study. Stud Neotrop Environ $35: 1-9$.

Goldstein DB, Ruiz Linares A, Cavalli-Sforza LL and Feldman MW (1995) Genetic absolute dating based on microsatellites 
and the origin of modern humans. Proc Natl Acad Sci USA 92:6723-6727.

Goodman SJ (1997) Rst Calc: A collection of computer programs for calculating estimates of genetic differentiation from microsatellite data and determining their significance. Mol Ecol 6:881-885.

Goudet J (2001) FSTAT, a program to estimate and test gene diversities and fixation indexes (version 2.3.9). Available from http://www.unil.ch/izea/softwares/fstat.html. Updated from Goudet (1995).

Goudet J, Raymond M, Meeüs T and Rousset F (1996) Testing differentiation in diploid populations. Genetics 144:19331940.

Grant P (1998) Evolution on Island. Oxford University Press, Nova York, $334 \mathrm{pp}$.

Guo SW and Thompson EA (1992) Performing the exact test for Hardy-Weinberg proportion for multiple allele. Biometrics 48:361-372.

Hedrick PW (1999) Perspective: Highly variable loci and their interpretation in evolution and conservation. Evolution 53:313-318.

Huchinson DW and Templeton AR (1999) Correlation of pairwise genetic and geographic distance measures: Inferring the relative influences of gene flow and drift on the distribution of genetic variability. Evolution 53:1898-1914.

Jin L and Chakraborty R (1995) Population structure, stepwise mutation, heterozygote deficiency and their implication in DNA forensics. Heredity 74:274-285.

Kimura M and Weiss GH (1964) The stepping stone model of population structure and the decrease of genetic correlation with distance. Genetics 49:561-576.

Koenig WD, Vuren DV and Hooge PN (1996) Detectability, phylopatry, and the distribution of dispersal distances in vertebrates. Trends Ecol Evol 11:514-517.

Leberg PL (2002) Estimating allelic richness: Effects of sample size and bottlenecks. Mol Ecol 11:2445-2449.

Lougheed SC, Gibbs HL, Prior KA and Weatherhead PJ (2000) A comparison of RAPD versus microsatellite DNA markers in population studies of the Massasauga rattlesnake. J Hered 91:458-463.

Loxterman JL, Moncrief ND, Dueser RD, Carson CR and Pagels JF (1998) Dispersal abilities and genetic population structure of insular and mainland Oryzomys palustris and Peromyscus leucopus. J Mammal 79:66-77.

Lynch M and Milligan BG (1994) Analysis of populational genetic structure with RAPD markers. Mol Ecol 3:91-99.

Maroja LS, Almeida F and Seuanez H (2003a) Genetic differentiation in geographically close populations of the water rat Nectomys squamipes (Rodentia, Sigmodontinae) from the Brazilian Atlantic Forest, Brazil. Genet Mol Biol 26:403410.

Maroja LS, Almeida F, Seuánez HN, Cerqueira R and Moreira MM (2003b) Nectomys squamipes microsatellites and homologous loci in sigmodontine rodents. J Hered 94:171-174.

Martins LR and Villwock JA (1987) Eastern South America quaternary coastal and marine geology: A synthesis. UNESCO Reports in Marine Science 43: Quaternary Coastal of West Africa and South America. UNESCO, Dakar, pp 28-96.

Matocq MD, Patton JL and da Silva MNF (2000) Population genetics structure of two ecologically distinct Amazonian spiny rats: Separating history and current ecology. Evolution 54:1423-1432.

Nei M (1978) Estimation of average heterozygosity and genetic distance from a small number of individuals. Genetics 89:583-590.

Neigel JE (1997) A comparison of alternative strategies for estimating gene flow from genetic markers. Annu Rev Ecol Syst 28:105-128.

Patton JL, da Silva MNF and Malcolm JR (1996) Hierarchical genetic structure and gene flow in three sympatric species of Amazonian rodents. Mol Ecol 5:229-238.

Raymond M and Rousset F (1995a) GENEPOP (version 1.2): Population genetics software for exact tests and ecumenicism. J Hered 86:248-249.

Raymond M and Rousset F (1995b) An exact test for population differentiation. Evolution 49:1280-1283.

Rice WR (1989) Analyzing tables of statistical tests. Evolution 43:223-225.

Ross KG, Shoemaker DD, Krieger MJB, DeHeer CJ and Keller L (1999) Assessing genetic structure with multiple classes of molecular markers: A case study involving the introduced fire ant Solenopsis invicta. Mol Biol Evol 16:525-543.

Rousset F (1997) Genetic differentiation and estimation of gene flow from $F$-statistic under isolation by distance. Genetics 145:1219-1228.

Sambrook J, Fritsch EF and Maniatis T (1989) Molecular cloning: A laboratory manual. Cold Spring Harbor Laboratory Press, Nova York, 999 pp.

Scheneider S, Roessli D and Excoffier L (2000) ARLEQUIN version 2.0. A software for population genetics data analysis. Genetics and Biometry Laboratory, Dept. of Anthropology and Ecology, University of Geneva, Switzerland.

Slatkin M (1989) Population structure and evolutionary progress. Genome 31:196-202.

Slatkin M (1993) Isolation by distance in equilibrium and nonequilibrium populations. Evolution 47:264-279.

Slatkin M (1995) A measure of population subdivision based on microsatellite allele frequencies. Genetics 139:457-462.

Smith LJ, Braylan RC, Nutkis JE, Edmundson KB, Downing JR and Wakeland EK (1987) Extraction of cellular DNA from human cells and tissues fixed with ethanol. Analytical Biochemistry 160:135-138.

Stewart WA, Dallas JF, Piertney SB, Marshall F, Lambin X and Telfer S (1999) Metapopulation genetic structure in water vole, Arvicola terrestris, in NE Scotland. Biol J Linn Soc Lond 68:159-171.

Weir BS and Cockerham CC (1984) Estimating $F$-statistic for the analysis of population structure. Evolution 38:1358-1370.

Wlasiuk G, Graza JC and Lessa EP (2003) Genetic and geographic differentiation in the Rio Negro tuco-tuco (Ctenomys rionegrensis): Inferring the roles of migration and drift from multiple genetic markers. Evolution 57:913926.

Whitlock MC and McCauley DE (1999) Indirect measures of gene flow and migration: $F$ st $=1 /(4 N m+1)$. Heredity $82: 117-125$.

Wright S (1943) Isolation by distance. Genetics 28:114-138.

Zenger KR, Richardson BJ and Vachot-Griffin A-M (2003) A rapid population expansion retains diversity within European rabbits in Australia. Mol Ecol 12:789-794.

Associate Editor: Yatiyo Yonenaga-Yassuda 